2. Березович Е. Л. Язык и традиционная культура: Этнолингвистические исследования. М.: Индрик, 2007. 599 с.

3. Верещагин Е. М., Костомаров В. Лингвострановедческая теория слова. М.: Рус.яз., 1980. 320 с.

4. Левицкий А.Э. Антропонимы как лингвокультурные маркеры. Лингвокультурные исследования: Язык лингвокультурологии: теория vs эмпирия. М.: ЛЕНАНД, 2016. С. 236-239.

5. Левицкий А. Э. Идиоматизация как средство пополнения системы английской фразеологии. Лексикология и фразеология: актуальные проблемы и решения. М.: ИПК МГЛУ «Рема», 2011. С. 92-101. (Вестн. Моск. гос. лингвист. ут-та; вып. 18 (624); сер. «Языкознание»).

6. Левицкий А. Э. Функциональная переориентация номинативных единиц современного английского языка: Монография. Житомир: Ред. издат. отд. ЖГПУ, 2001. 168 с.

7. Суперанская А.В., Сталтмане В.Э., Подольская Н.В., Султанов А.Х. Теория и методика ономастических исследований. М.: ЛКИ, 2007. 256 с.

DOI https://doi.org/10.30525/978-9934-26-110-7-50

\title{
PHARMACEUTICAL NAMES OF PLANTS IN LATIN AND ENGLISH
}

\author{
Lozenko V. V. \\ Candidate of Philological Sciences, \\ Associate Professor at the Latin language \\ and medical terminology department \\ Kharkiv National Medical University \\ Kharkiv, Ukraine
}

Names of plants is the wide field of research as regards to the origin of their names, the specificity of translation into other languages etc. This study is devoted to comparative analysis of pharmaceutical names of plants in Latin and English.

Pharmaceutical names of plants, trees and flowers are known to be different from botanical ones. For example, the Latin botanical name of senna (Engl. Cassia, senna) is Cassia acutifolia, the pharmaceutical name is Senna. Sometimes the botanical name coincides with the pharmaceutical one completely: Mentha piperita (peppermint) can be used in botanical nomenclature and pharmaceutical terminology. 
It is worth focusing on the fact that in English there are used latinized forms of names in academic literature. For example, Latin pharmaceutical name Althaea is translated into academic English as Althaea. Meanwhile, in common English and sometimes in academic scientific books, next to latinized forms of plants, one can find English names of this plant: marsh mallow, sweat-weed.

The research has found out that latinized forms are often used when it comes to such names of plants as Eucalyptus (Engl. eucalyptus), Adonis (Engl. adonis), Ginseng (Engl. ginseng), Absinthium (Engl. absinth), Aloë (Engl. aloe). It is worth outlining that one can see English names of plants in academic literature when it comes to names of plants which derive their origin from mythology: for instance, Adonis (Latin name) and its English equivalents pheasant's eye, spring pheasant's eye, yellow pheasant's eye and false hellebore. Adonis is a handsome young man from Greek mythology. Another name, pheasant's eye, hightligths the resemblance between the flower and the red eye of a pheasant.

It is possible to use latinized form or an English form of a name as regards to Digitalis (Engl. digitalis, foxglove). It is worth outlining that Latin names of some plants are different from English ones. Such names require memorizing in Latin and English: Foeniculum (Engl. fennel), Hypericum (St. John's wort), Helichrysum arenarium (sandy everlasting), Frangula (buckthorn), Leonurus (motherwort), Crataegus (hawthorn), Salvia (sage), Betula (birch), Quercus (oak), Urtica (nettle), Glycyrrhizza (licorice), Convallaria (lily of the valley), Hippophaë (sea-buckthorn).

In conclusion, both Latin and English names of plants are used in academic literature. It requires consulting a dictionary or an academic reference book for correct usage of names.

\section{References:}

1. Ботанико-фармакогностический словарь / под ред. К. Ф. Блиновой, Г. П. Яковлева. Москва: Высшая школа, 1990. 270 с.

2. Бурмистрова Т. Н. Лингвокультурная интерпретация сакральных фитонимов с прозрачной внутренней формой. Лингвокультурология, 2008. C. 33-40.

3. Медицинская ботаника / под ред. Л. М. Серой. Харьков: НФаУ: Золотые страницы, 2003. 364 с.

4. Gledhill D. The names of plants. New-York, Cambridge: Cambridge univ.press. 2008. $426 \mathrm{c}$. 